\title{
Conditioning Regimens for Hematopoietic Cell Transplantation in Primary Immunodeficiency
}

\author{
S. H. Lum ${ }^{1} \cdot$ M. Hoenig ${ }^{2} \cdot$ A. R. Gennery ${ }^{1,3} \cdot$ M. A. Slatter ${ }^{1,3}$ \\ Published online: 18 November 2019 \\ (C) The Author(s) 2019
}

\begin{abstract}
Purpose of Review Hematopoietic cell transplantation (HCT) is an established curative treatment for children with primary immunodeficiencies. This article reviews the latest developments in conditioning regimens for primary immunodeficiency (PID). It focuses on data regarding transplant outcomes according to newer reduced toxicity conditioning regimens used in HCT for PID.

Recent Findings Conventional myeloablative conditioning regimens are associated with significant acute toxicities, transplantrelated mortality, and late effects such as infertility. Reduced toxicity conditioning regimens have had significant positive impacts on HCT outcome, and there are now well-established strategies in children with PID. Treosulfan has emerged as a promising preparative agent. Use of a peripheral stem cell source has been shown to be associated with better donor chimerism in patients receiving reduced toxicity conditioning. Minimal conditioning regimens using monoclonal antibodies are in clinical trials with promising results thus far.

Summary Reduced toxicity conditioning has emerged as standard of care for PID and has resulted in improved transplant survival for patients with significant comorbidities.
\end{abstract}

Keywords Primary immunodeficiency $\cdot$ Hematopoietic cell transplantation $\cdot$ Reduced toxicity conditioning $\cdot$ HCT outcome Transplant-related survival

\section{Introduction}

Primary immunodeficiency (PID) comprises a large, heterogeneous group of disorders that result from defects in immune system development and/or function. Long considered as rare diseases, recent studies show that one in 2000-5000 children younger than 18 years is thought to have a PID. There are now

This article is part of the Topical Collection on Immune Deficiency and Dysregulation

\section{A. Slatter}

mary.slatter@nuth.nhs.uk

1 Children's Haematopoietic Stem Cell Transplant Unit, Great North Children's Hospital, Newcastle upon Tyne Hospital NHS Foundation Trust, Newcastle upon Tyne, UK

2 Department of Pediatrics, University Medical Center Ulm, Ulm, Germany

3 Institute of Cellular Medicine, Newcastle University, Newcastle upon Tyne, UK around 350 single-gene inborn errors of immunity and the underlying phenotypes are as diverse as infection, malignancy, allergy, autoimmunity, and autoinflammation. Therefore, presenting features, severity, and age of diagnosis vary immensely. Hematopoietic cell transplantation (HCT) is a wellrecognized curative therapy for many of these PIDs. Since the first transplant took place in 1968, utility of HCT was initially limited by high rates of graft failure and transplant-related morbidity and mortality; however, transplant survival and graft outcomes have significantly improved, particularly since $2000[1,2]$. Many factors have contributed to this improvement including earlier diagnosis, a detailed graft selection hierarchy, superior HLA matching technology, improved methods for graft manipulation, greater availability of grafts, improved supportive care, vigilant infection surveillance and pre-emptive treatment, and more effective antimicrobial therapy. In the modern era, graft engineering, additional cellular therapy, and pharmacokinetic-guided conditioning regimens enable precise personalized transplant care including prescription of graft components, better cell-dosed grafts, and a patient-tailored conditioning regimen $[3,4 \bullet, 5 \bullet \bullet$. 
Short-term transplant survival outcomes must be carefully distinguished from long-term disease outcomes and late effects of transplant. As survival from transplant has improved, more attention is now given to long-term disease outcomes and quality of life. Therefore, the goal of conditioning is to give the least toxic regimen with minimal short- and long-term side effects but still achieve cure of the underlying condition. This review will focus on newer conditioning regimens, how they have changed, and possible future directions. It is important to note that success does not simply depend on which conditioning chemotherapeutic agents are employed but on a combination of factors such as additional serotherapy, timing and dosage, and stem cell source. In almost all cases, preparative conditioning with a combination of chemotherapeutic agents, with or without monoclonal antibodies, is required for successful engraftment and stable robust long-term immune reconstitution.

\section{Definition}

The intensity of the conditioning regimen can vary substantially and has been classified as myeloablative conditioning (MAC), reduced toxicity conditioning (RTC), reduced intensity conditioning (RIC), and minimal intensity conditioning (MIC) in decreasing order (Fig. 1). MAC, consisting of alkylating agents with or without total body irradiation (TBI), is expected to myeloablate the recipient's hematopoiesis which does not allow for autologous hematological recovery. This aims to prevent rejection by the use of supralethal chemotherapy to remove hostversus-graft reaction and create marrow niche space for donor stem cells. Newer myeloablative chemotherapy agents are being explored to reduce toxicity and enable safer HCT. These reduced toxicity conditioning (RTC) regimens, including pharmacokinetic targeted busulfanfludarabine (Bu-Flu) and treosulfan-fludarabine, have a comparable myeloablative effect with conventional MAC but reduced organ toxicities. Compared to MAC, RIC has been traditionally characterized by reversible myelosuppression in the absence of stem cell rescue, reduced regimen-related toxicity, and a higher incidence of mixed chimerism. MIC is strictly non-myeloablative, does not eradicate host hematopoiesis, and allows relatively rapid autologous hematopoietic recovery without a transplant, but adequately myelosuppresses the recipient to enable at least partial donor engraftment.

\section{Myeloablative Conditioning Regimens in PID}

Historically, conditioning therapy prior to HCT in PID was based on the combination of alkylators busulfan and cyclophosphamide. However, many children with PID have significant comorbidities at the time of HCT, and these conventional myeloablative preparative regimens are associated with significant toxicity and a relatively high incidence of transplant mortality, as well as long-term sequelae. While initial results may have been acceptable, appreciation of acute conditioning toxicities and recognition of long-term sequelae mean that few centers now approach transplantation of PID patients with conventional myeloablative preparative regimens (Table 1) [6-9].

\section{RTC Regimens in PID}

The use of reduced toxicity conditioning regimens are now generally preferred for patients with PID as there is no malignant disease to eradicate, stable mixed chimerism achieves cure for many diseases, and many patients enter HCT with chronic infections and end-organ comorbidities. Additionally, many patients are infants at the time of transplant and may be more susceptible to toxicity [10]. Less toxic regimens may reduce early and late adverse effects, particularly infertility [4•]. There are several reduced toxicity regimens that have been utilized by investigators in PID (Table 2) $[14 \cdot, 49,50]$.

\section{Fludarabine and Treosulfan}

Treosulfan (L-treitol-1,4-bis-methanesulfonate) is a prodrug and a water-soluble bifunctional alkylating agent which has been used for many years as treatment for various neoplasms, but more recently as part of conditioning for HSCT. In addition to myeloablative properties, it has marked immunosuppressive properties which contribute to the achievement of stable engraftment posttransplant. It causes relatively low organ toxicity compared to high-dose busulfan and cyclophosphamide leading to fewer complications such as venoocclusive disease of the liver.

The first successful allogeneic transplant in a child using treosulfan was performed in 2000 and since then many reports have confirmed its efficacy and safety in both malignant and non-malignant disorders $[11 \bullet \bullet, 12 \bullet, 13,14 \bullet, 15-18]$. Slatter et al. first published results of 70 children with PID who received treosulfan in combination with either cyclophosphamide $(n=30)$ or fludarabine $(n=40)$ with an overall survival of $81 \%$ (median follow-up 19 months) equivalent in those aged less or greater than 1 year at time of transplant [13]. Toxicity was low but worse after cyclophosphamide, and $\mathrm{T}$ cell chimerism was significantly better after fludarabine [18]. Slatter et al. more recently reported 160 patients who had received conditioning with treosulfan and fludarabine achieving a probability of 2-year survival of $87.1 \%$ with a high level of complete or stable mixed chimerism in the diseased cell 


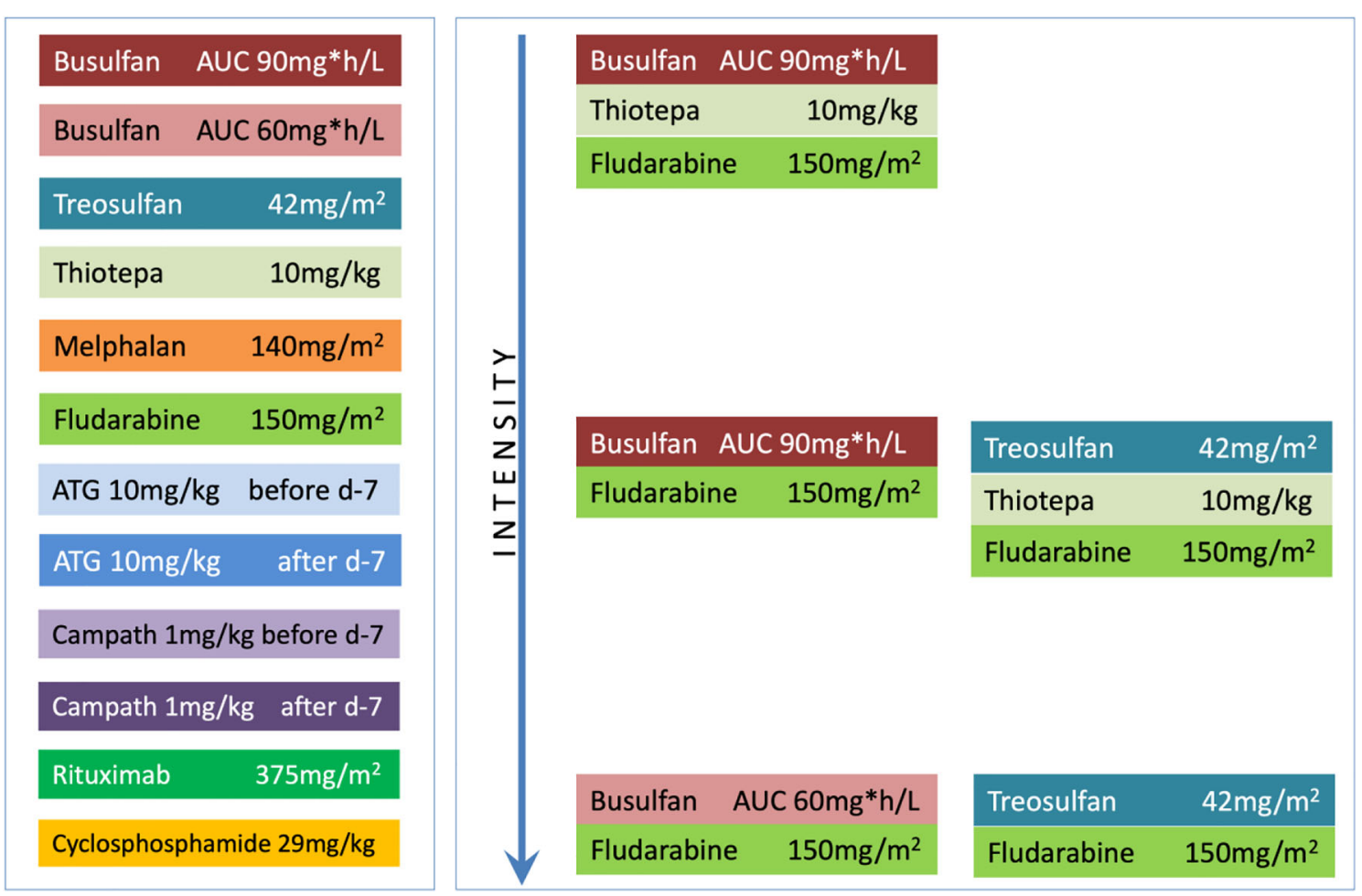

Fig. 1 Intensity of conditioning regimen according to chemotherapy, pharmacokinetic guided dosing, timing of serotherapy, and combination of chemotherapy

lineage, sufficient to cure disease $[11 \bullet \bullet$. There was a high survival rate in children transplanted under 1 year of age in whom toxicity can be a problem with conventional and other reduced intensity conditioning regimens [24, 25]. A 100-day survival of $94 \%$ demonstrated the low toxicity of this regimen making it suitable for patients with PID who often have infection and organ damage prior to HCT. In this series, a higher level of myeloid chimerism was found in recipients of PBSC compared to $\mathrm{CB}$ and $\mathrm{BM}$, without an increased risk of grade III/IV acute or chronic graft-versus-host disease (GvHD). This highlights the importance of the whole transplant package including stem cell source and serotherapy when tailoring therapy [26].

Excellent results were reported by Lehmberg et al. in 19 patients with hemophagocytic lymphohistiocytosis (HLH) following HCT with treosulfan, fludarabine, alemtuzumab, with or without thiotepa, all of whom survived with a median follow-up of 16 months [16].

Haskologlu et al. reported 15 patients with PID who had a high risk of developing transplant-related toxicity due to previous lung and liver damages and were given treosulfan-based conditioning [27]. At 32 months follow-up, the overall survival was $86.7 \%$ with excellent chimerism and low conditioning associated morbidity despite the high-risk population.

Mixed chimerism is sufficient to achieve cure in some nonmalignant disorders, but the specific diagnosis and level of chimerism needed to achieve cure must be taken into account when balancing the need for increased myeloablation against short- and long-term toxicities from the conditioning regimen. The addition of thiotepa is common in order to increase the intensity of the regimen, but there are few reports of any comparison in outcomes comparing treosulfan and fludarabine with or without additional thiotepa. Yael Dinur-Schejter et al. reported 44 patients with non-malignant diseases: 19 received treosulfan with fludarabine $66.7 \%$ of whom achieved complete engraftment compared to $94.7 \%$ of 20 patients who received additional thiotepa, but this did not translate into any significant difference in overall or event free survival [15].

\section{Fludarabine and Busulfan}

Traditionally, busulfan $(\mathrm{Bu})$ was used in combination with cyclophosphamide $(\mathrm{Cy})$ as the standard myeloablative conditioning regimen for HCT for both malignant and nonmalignant disorders in both adult and pediatric patients. Cyclophosphamide is increasingly being substituted with fludarabine (Flu), a nucleoside analogue with immunosuppressive properties, to provide a less toxic but equally effective regimen [19, 21, 28].

Harris et al. compared 1400 children who received $\mathrm{Bu}-\mathrm{Cy}$ to 381 who received $\mathrm{Bu}$-Flu. Busulfan doses were comparable between the 2 groups and the majority had pharmacokinetic monitoring. Eight hundred and three had non-malignant disorders including 195 with PID who received Bu-Cy and 86 who received $\mathrm{Bu}$-Flu. Nine hundred and seventy-eight had malignant disorders. Children receiving $\mathrm{Bu}$-Flu for non-malignant 


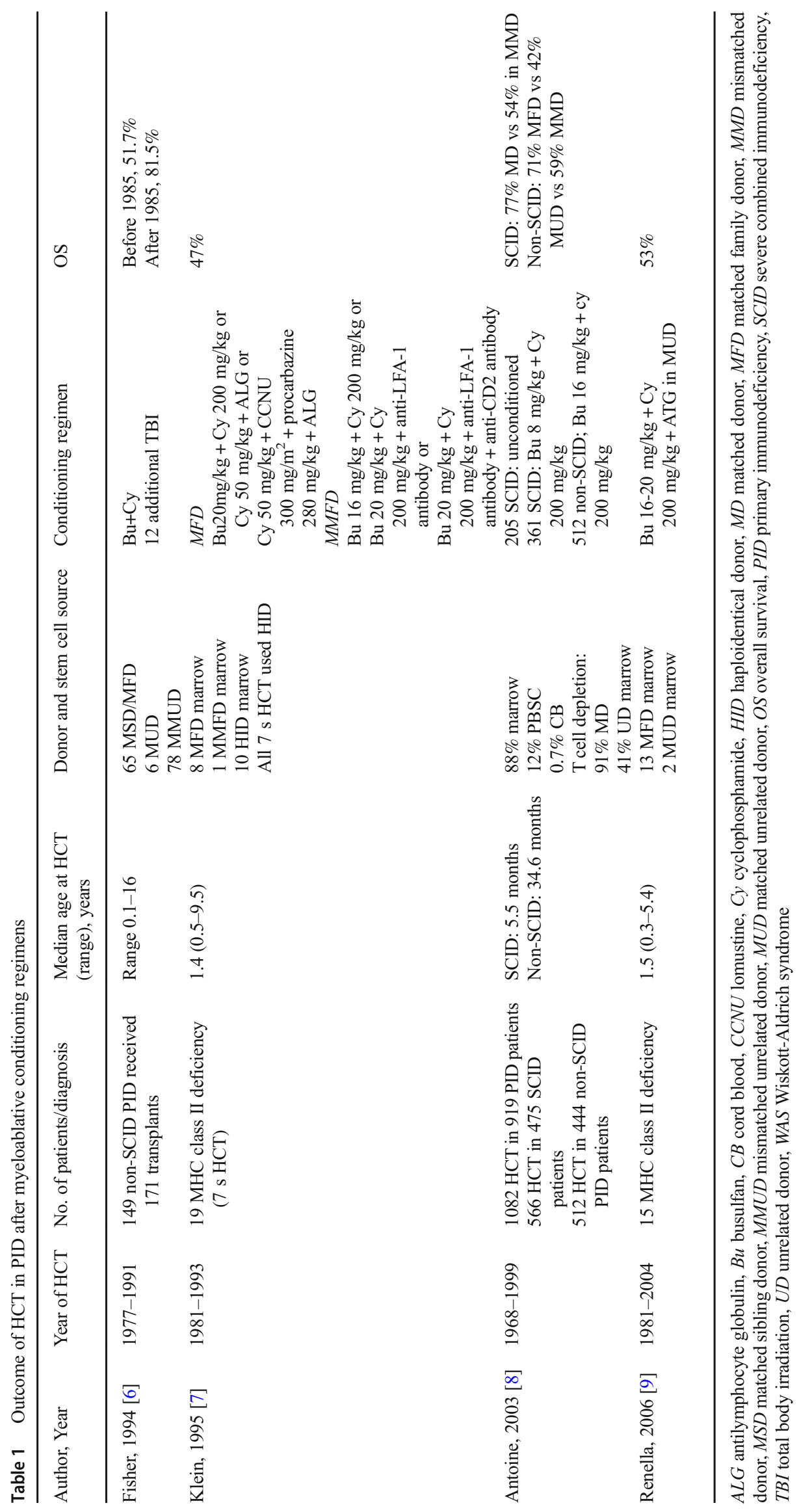




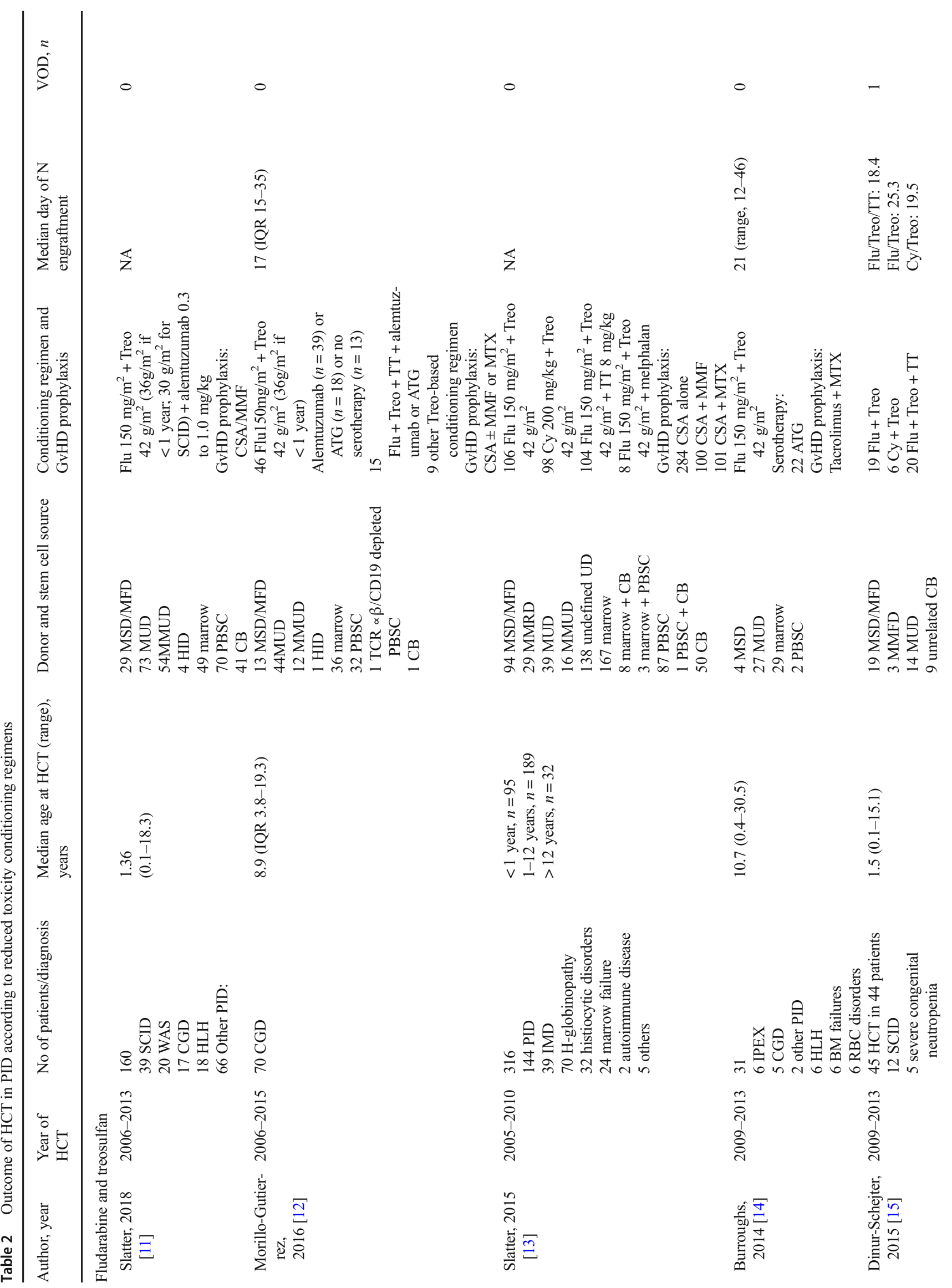




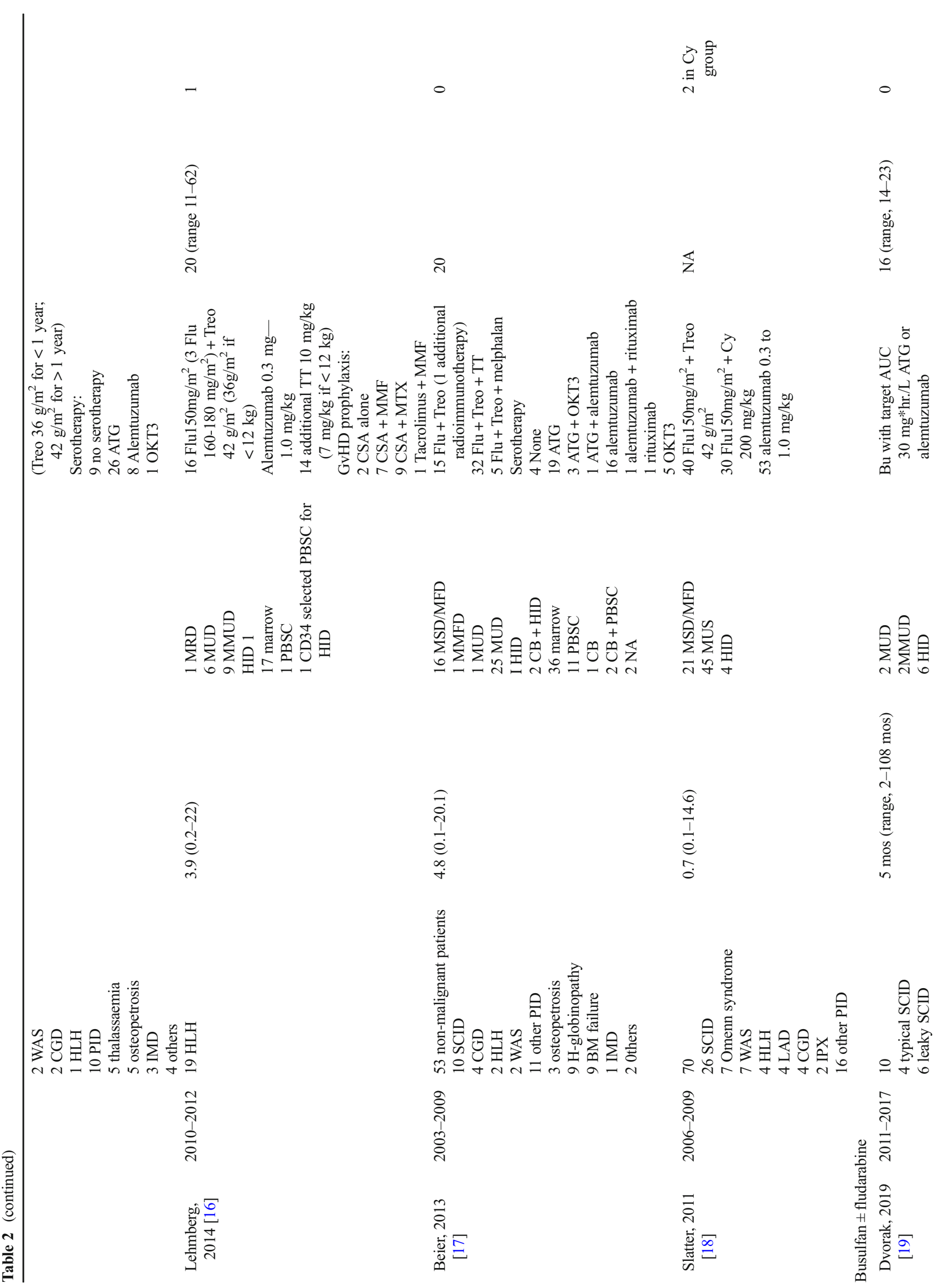




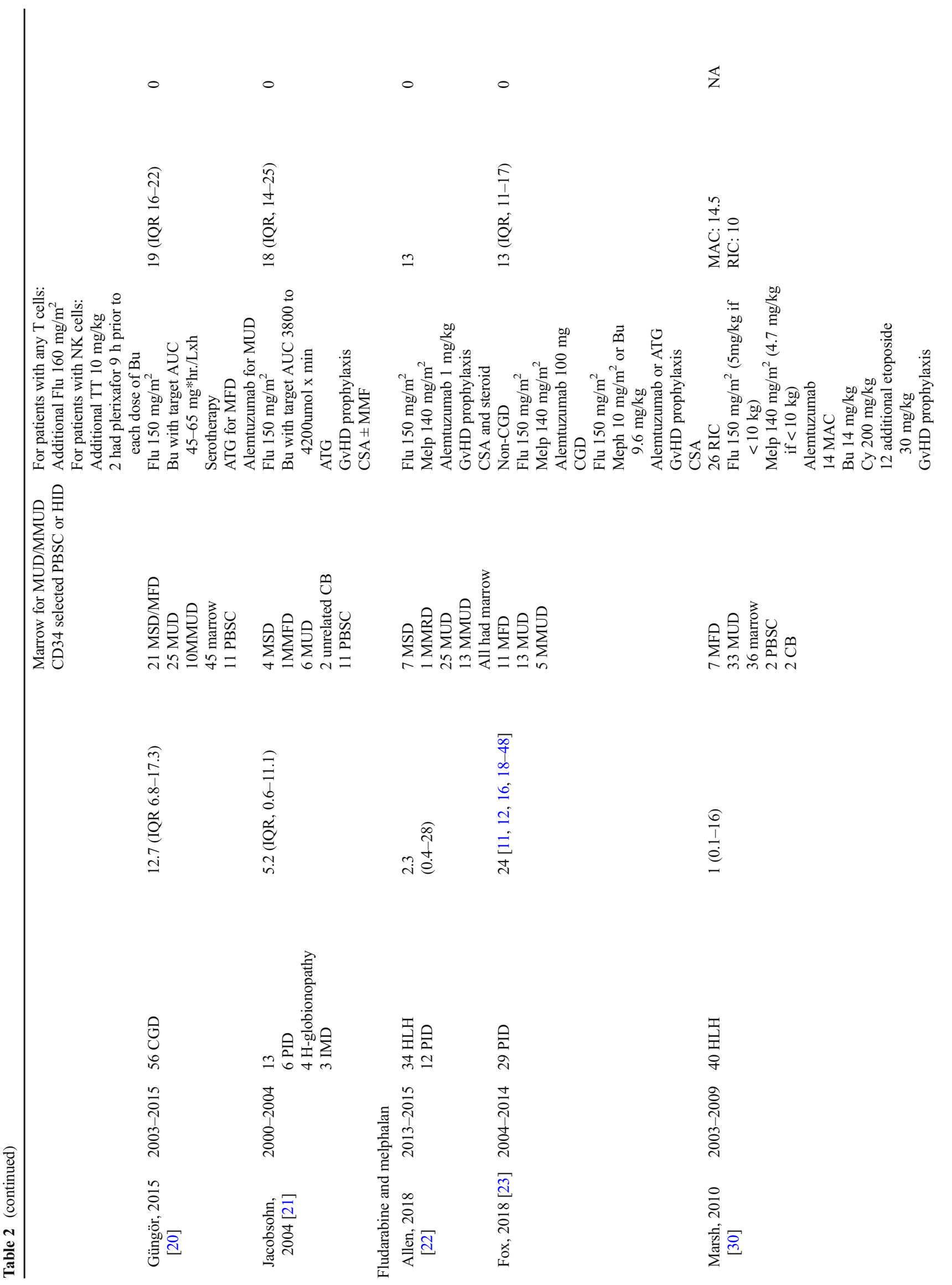




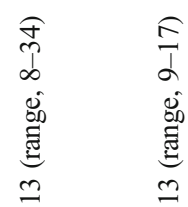

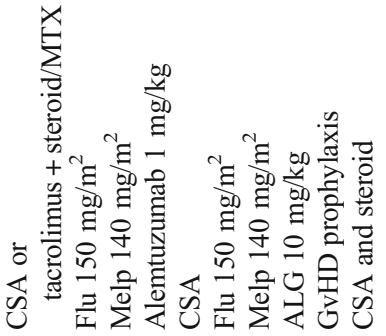
菏入

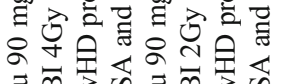

$\stackrel{-}{0}$

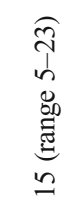

$\overleftrightarrow{z}$<smiles>C#CC(=C)C#C</smiles>

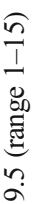

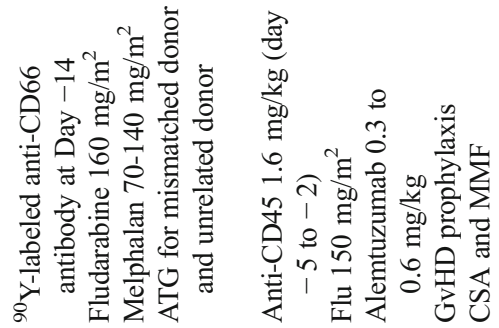

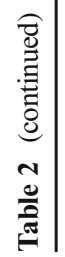

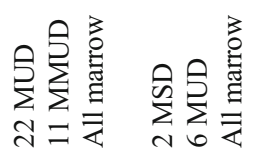

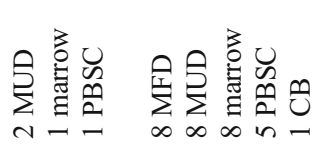

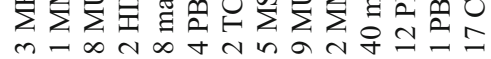

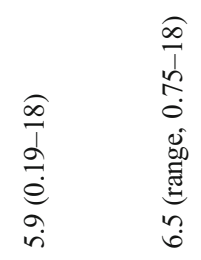

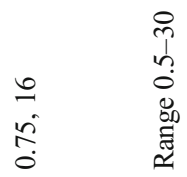

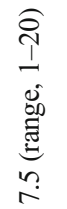

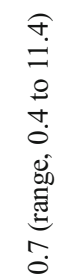

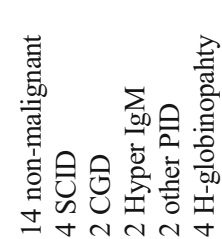

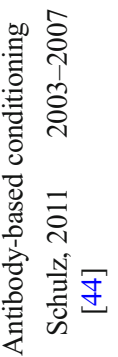

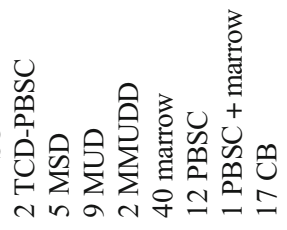

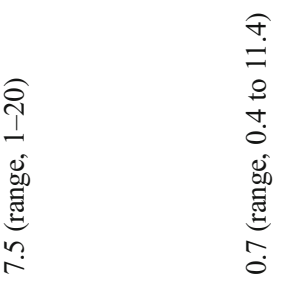

至

m心i

ठे

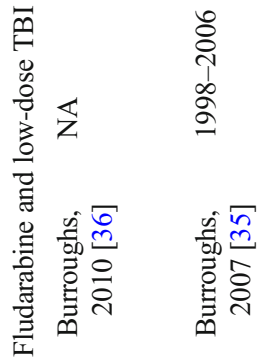

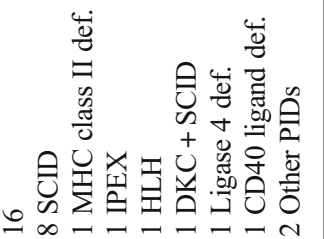

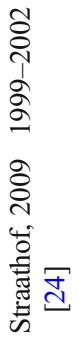

ᄒ

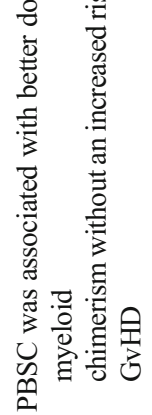

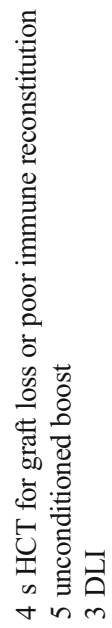

$\infty \stackrel{\infty}{\infty}$

琴茥

究芯

$\infty \infty \infty$

$\ddot{\tilde{O}} \ddot{\ddot{O}}$

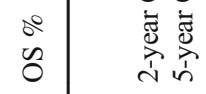

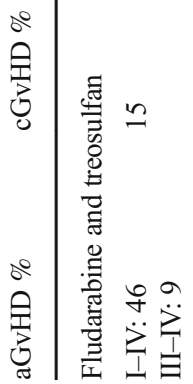




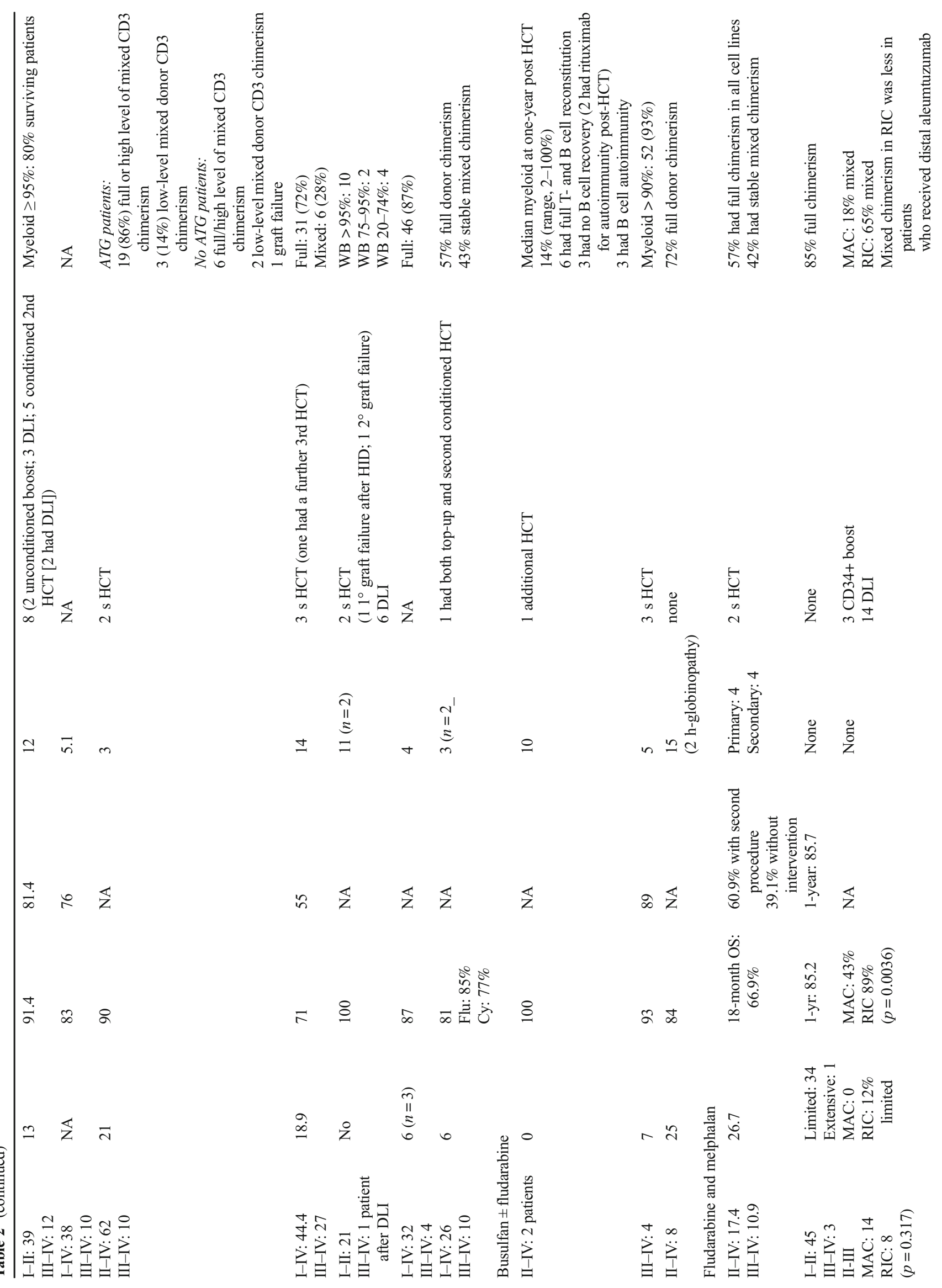


52 Page 10 of 18

Gur Allergy Asthma Rep (2019) 19: 52

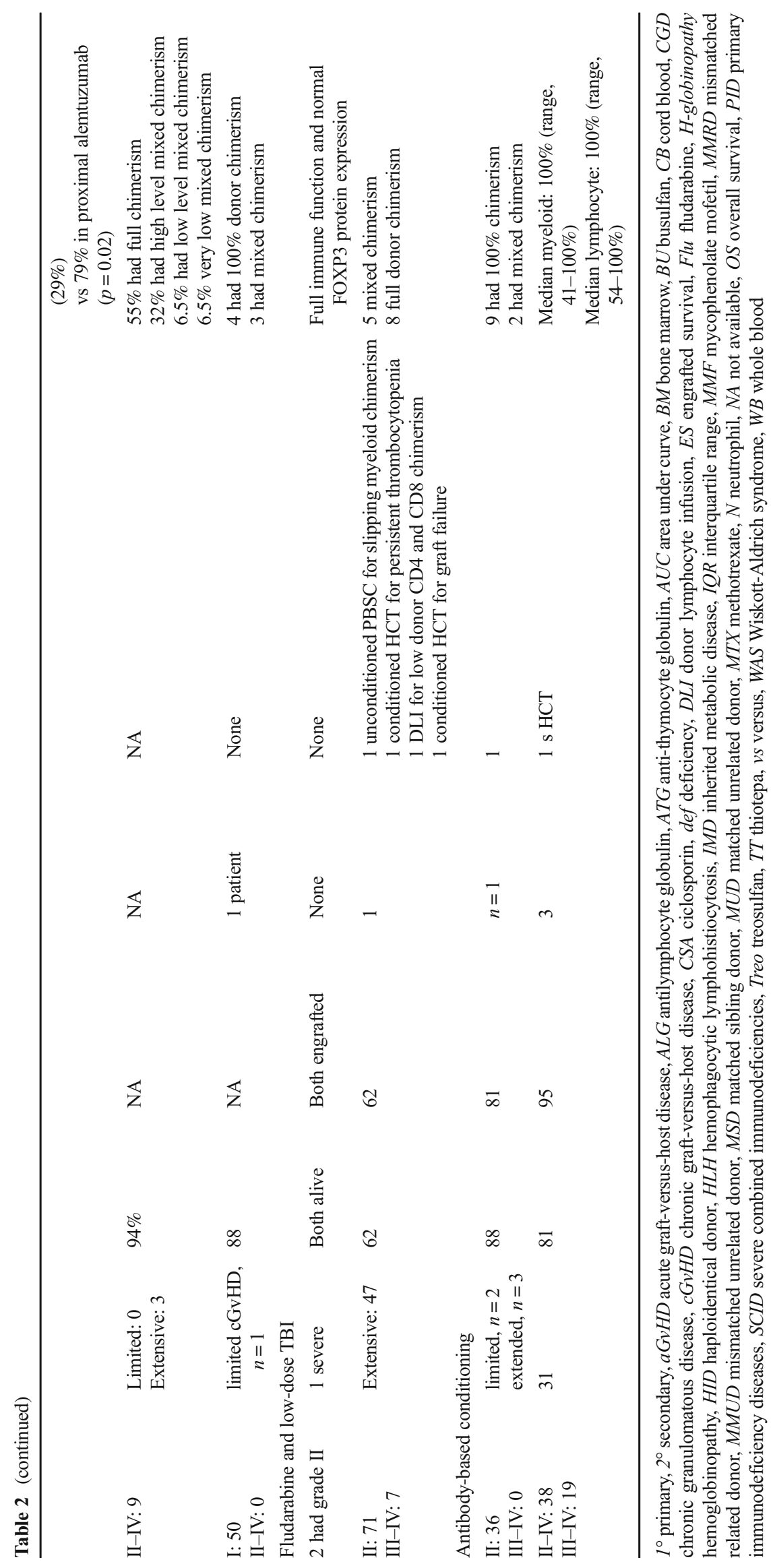

Springer 
conditions experienced less toxicity than those receiving $\mathrm{Bu}-\mathrm{Cy}$, but survival was comparable. Children with malignancy had shorter postrelapse survival with Bu-Flu than Bu-Cy although transplant-related mortality and relapse were similar [29].

The pharmacokinetics of busulfan have been studied extensively and the use of a lower target area under the curve $(45-65 \mathrm{mg} / \mathrm{L} \times \mathrm{h})$ combined with fludarabine has been pioneered by Tayfun Güngör and colleagues in Zurich. Particularly impressive results have been seen using this regimen for patients with chronic granulomatous disease (CGD). Fifty-six children and young adults with CGD were reported, many of whom had high-risk features such as intractable infections and autoinflammation. Twenty-one HLA-matched related-donor and 35 HLA-matched unrelated-donor transplants were done. The 2-year probability of overall survival was $96 \%$ (95\% CI 86.46-99.09), and of EFS was $91 \%$ (79.78-96.17). Graft-failure occurred in 5\% (three of 56) of patients. The cumulative incidence of acute GvHD of grade III-IV was $4 \%$ (two of 56) and of chronic GvHD was $7 \%$ (four of 56). Stable $(\geq 90 \%)$ myeloid donor chimerism was documented in $52(93 \%)$ surviving patients [20••].

Dvorak et al. have recently reported the result of the use busulfan at a lower target area under the curve $(30 \mathrm{mg} / \mathrm{L} \times \mathrm{h})$ alone or in combination with fludarabine or thiotepa in 10 patients with severe combined immunodeficiency. All the patients survived, one patient required second HCT, and 3 had no B cell reconstitution [19].

\section{RIC in PID}

\section{Fludarabine and Melphalan}

Increasing recognition of the significant toxicities associated with conventional doses of busulfan and cyclophosphamide, particularly in very young infants and especially in those with pre-existing end organ damage, led to the adoption of immunosuppressive-based, rather than myelo-ablative-based regimens, with fludarabine and melphalan. The results, principally in those with significant preexisting comorbidities, were striking with significantly improved early survival $[22,23,30,31$, 49]. However, donor chimerism was not always optimal, and there was a high incidence of late viral reactivation, and late onset acute GvHD. Furthermore, toxicities in infants $<1$ year of age remained significant [25]. Melphalan in particular has been associated with cardiac toxicities [32]. Good results have been reported for patients with hemophagocytic lymphohistiocytosis [33]. Patients with X-linked inhibitor of apoptosis protein (XIAP) deficiency, which is difficult to transplant, also have good outcomes reported using fludarabine and melphalan-based regimens [34]. It has been used in adults with PID with good transplant survival [23]
While the approach remains attractive in terms of reduced toxicities, concerns regarding late graft failure and high mortality in the $<12$-month-aged infants remain.

\section{Minimal Intensity Conditioning for PID}

\section{Fludarabine and Low-Dose TBI}

Burroughs et al. from the Seattle group have reported the transplant outcome of using fludarabine and low-dose TBI in 14 PID patients with significant preexisting organ dysfunction and infections. All received posttransplant GvHD prophylaxis with cyclosporin and mycophenolate mofetil but no serotherapy. Overall survival at 3 years was $62 \%$, but there were high rates of acute (79\%) and extensive chronic GvHD (47\%) [35]. One had graft failure and an additional three patients required a second procedure for decreasing chimerism. Of 10 evaluable patients, 8 had correction of immune deficiency with stable chimerism. However, the high rate of GvHD has limited the broader use of this conditioning regimen in children with PID $[35,36]$.

\section{Antibody-Based}

While conditioning regimens have undoubtedly become less toxic, the ability to achieve donor chimerism without the use of chemotherapeutic agents, particularly in patients with nonmalignant disease, is extremely attractive. Furthermore, some primary immunodeficiencies have significant toxicities associated with the administration of alkylating agents, due to the nature of the molecular defect, leading to serious long-term effects or early mortality [37-39]. A number of different strategies have been employed to minimize the exposure to chemotherapeutic agents by the use of antibodies to aid stem cell engraftment, with or without adjunct chemotherapy.

\section{Anti-CD45 Antibodies}

CD45 is selectively expressed on all leucocytes and hematopoietic progenitors but is absent on non-hematopoietic tissues. Straathoff and colleagues studied 16 patients with PID who were less than 1 year of age or had significant preexisting comorbidities and were felt not suitable for conventional reduced intensity conditioning [24]. The conditioning regimen was comprised of alemtuzumab $0.2 \mathrm{mg} / \mathrm{kg}$ daily for 3 days for unrelated donors, or $0.1 \mathrm{mg} / \mathrm{kg}$ daily for 3 days for matched sibling donors on day -8 to day -6 , clinical grade rat antiCD45 (YTH24.5and54.12) $0.4 \mathrm{mg} / \mathrm{kg}$ on day -5 to day -2 , fludarabine $\left(30 \mathrm{mg} / \mathrm{m}^{2}\right.$ daily for 5 days on day -8 to day -4$)$ and cyclophosphamide $\left(300 \mathrm{mg} / \mathrm{m}^{2}\right.$ daily for 4 days on day 7 to day -4$)$. Twelve patients were alive and well at the end of the study, one failed to engraft and was successfully re- 
transplanted, and 3 died-none of conditioning toxicity. Donor chimerism was variable but high level and sufficient to cure disease in the survivors.

\section{Radioimmunotherapy}

Radioimmunotherapy is an attractive concept for conditioning of patients with PIDs as it exploits of the physical cytotoxic effect of radiation and reduces the toxicity to other organ systems by its internal application and the conjugation of radioisotopes to specific antibodies [40]. Radioisotopes emitting $\alpha$, $\beta$ or $\gamma$-radiation of calculated intensity can be brought in direct proximity to the cells of interest. This enables malignant cells to be eradicated or benign hematopoietic cells to be depleted as part of conditioning before autologous or allogeneic HSCT. The method was developed to allow better and more specific control of malignant cells in the setting of HSCT without an increase in non-relapse mortality. Considerable clinical data was accumulated with conjugates of ${ }^{90} \mathrm{Yttrium}$ or ${ }^{131}$ Iodine to anti-CD20 antibodies in the treatment of patients with refractory or recurrent $\mathrm{B}$ cell non-Hodgkin lymphoma (B-NHL). The drugs were used in combination with chemotherapy to prepare patients for autologous and allogeneic stem cell transplantation. This experience resulted in the approval of two drugs (Zevalin $\circledast$ and Bexxar $\circledast$ ) by the FDA at the beginning of the century [40].

The use of RIT for the treatment of leukemias or for myeloablation in non-malignant disease until present is limited to clinical studies. A conjugate of ${ }^{131}$ Iodine to anti-CD45-antibody was explored in the treatment of patients with AML and high-risk MDS, again a combination of RIT with conventional myeloablative or immunosuppressive drugs was used for conditioning before allogeneic HSCT [41, 42]. CD45 is expressed on most AML and ALL blasts as well as on virtually all developing and mature cells of normal hematopoiesis. Radiolabeled antiCD45 antibody doses up to 43 Gy were administered to the bone marrow in combination with RIC and allogeneic transplantation with good tolerance and without additional toxicity in younger adult patients with AML and MDS [43]. For children, limited published data exists for the use of RIT for pretransplant conditioning. A conjugate of ${ }^{90}$ Yttrium to an antibody targeting CD66 was used in combination with melphalan and fludarabine or TBI for the treatment of children with considerable comorbidities with malignant and non-malignant disease. ${ }^{90}$ Yttrium emits pure $\beta$-radiation with a maximum range of $11 \mathrm{~mm}$ and a half-life of 2.7 days [44]. With these qualities, no isolation of the pediatric patients was necessary, but the dosimetry had to be performed with another isotope, emitting $\gamma$-radiation to be detected in a $\gamma$-camera. CD66 is abundantly present on mature myeloid cells but usually not expressed on malignant blasts. The therapeutic principle of RIT with this antibody in malignant disease therefore relies on the so-called cross-fire effect, which describes the indirect depletion of blasts by binding of the antibody to cells in close proximity [40]. In order to avoid graft rejection in unrelated or mismatched grafts, recipients received serotherapy with ATG in this setting. Fifteen of 16 children with non-malignant disease survived the procedure, 13/15 with complete donor chimerism. The Kaplan-Meier estimation for disease-free survival at 24 months was $94 \%$. This clearly documented feasibility of and reliable myeloablation by RIT in children and young adults with non-malignant disease.

\section{Anti-CD117 Antibodies}

The molecule CD117 (c-Kit receptor) is expressed on hematopoietic stem cells at all stages of development. Interactions with the ligand of CD117, stem cell factor, are crucial for hematopoietic stem cell survival, and this signaling pathway plays a critical role in the homing, adhesion, maintenance, and survival of hematopoietic stem cells in the hematopoietic niche. Preclinical studies demonstrated that using an antibody against CD117 to impede CD117-stem cell factor signaling selectively depleted hematopoietic stem cells with no effect on differentiated progenitor or mature cell lineages, and enabled engraftment of donor cells [45]. A clinical trial is currently in progress using anti-CD117 antibody alone to treat patients with primary immunodeficiencies (AMG191 Conditioning/CD34 + CD90 Stem Cell Transplant Study for SCID Patients, ClinicalTrials.gov Identifier: NCT02963064). The early results of this dose finding study show that some donor stem cell chimerism, leading to donor $\mathrm{T}$ and $\mathrm{B}$ lymphocyte chimerism can be achieved [46]. These preliminary data are extremely exciting and potentially lead the way to a step change in approaches to conditioning in patients with PIDs.

\section{Conditioning for Haploidentical Donor Transplant}

As the outcomes of HCT using newer T cell depletion methods have improved, there is an increasing number of haploidentical transplants performed for both SCID and non-SCID PID. Various non-myeloablative conditioning regimens have been used in T-deplete and T-replete haploidentical transplant (Table 3) [5••, 47, 48, 51]. The Great North Children's Hospital (GNCH) group in Newcastle has used fludarabine, treosulfan, ATG (Grafalon), and ritixumab for patients who received CD3 TCR ab/CD19 depleted peripheral blood stem cells. Patients with non-SCID PID received additional thiotepa. 


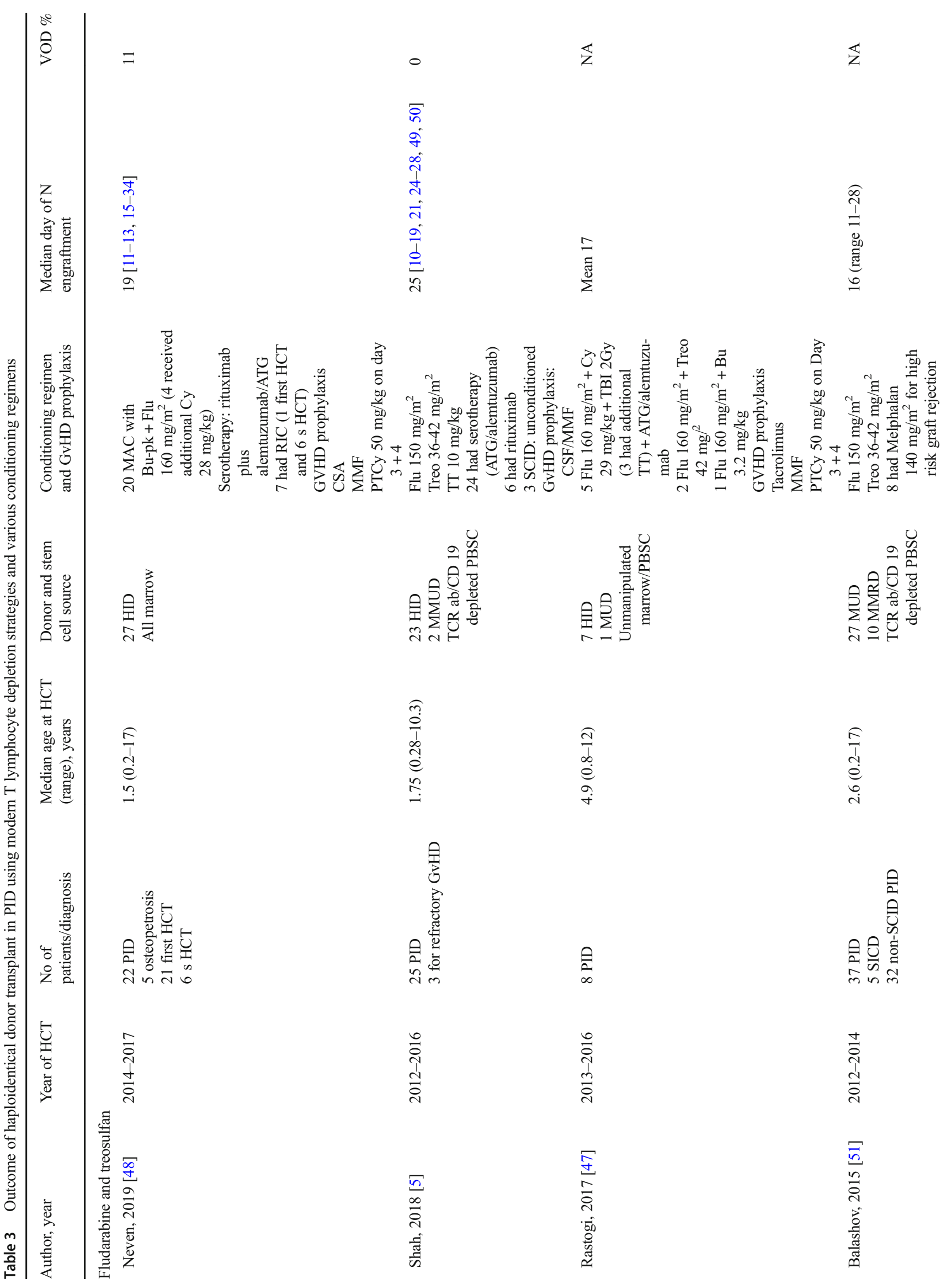


The overall survival was comparable with family and unrelated donor transplant using a similar conditioning regimen $[18,51]$. Neven et al. reported the outcome of Bu-Flu in 22 patients with PID received haploidentical transplant using posttransplant cyclophosphamide. The overall survival and donor chimerism were good, but $48 \%$ had acute GvHD and 24.2\% had chronic GvHD.

\section{Pharmacokinetic Studies}

Although levels of busulfan have been measured for many years, to target the narrow myeloablative therapeutic window, minimize toxicity from supra-therapeutic levels and avoid sub-myelo-ablation and rejection, it is only recently that the importance of pharmacokinetic monitoring of other agents of the conditioning cocktail has been appreciated.

\section{Fludarabine Pharmacokinetics}

Ivaturi et al. prospectively studied the pharmacokinetics and pharmacodynamics of 133 children undergoing HCT for a variety of disorders with a variety of conditioning regimens but all included fludarabine. Young age and renal impairment were found to lead to an increased exposure. In the setting of malignancy, disease-free survival (DFS) was highest 1 year after HCT in subjects achieving a systemic fludarabine plasma (f-ara-a) cumulative area under the curve (cAUC) greater than $15 \mathrm{mg}$ *hour/L compared to patients with a cAUC less than $15 \mathrm{mg} *$ hour/L (82.6\% versus $52.8 \%, p=0.04)$ [52]. Further development of model-based dosing may minimize toxicity and maximize efficacy, resulting in superior outcomes for malignant and non-malignant patients.

\section{Treosulfan Pharmacokinetics}

Relatively high variability of treosulfan pharmacokinetics in pediatric patients may raise the need for implementing therapeutic drug monitoring and individual dose adjustment in this group. Vander Stoep et al. and Mohanan et al. recently published the first results of a relationship between the exposure of treosulfan and early toxicity, as well as clinical outcome, in children undergoing conditioning prior to HSCT. In the former study, patients with an $\mathrm{AUC}>1650 \mathrm{mg} \mathrm{h} / \mathrm{L}$ demonstrated a statistically higher incidence of mucosal and skin toxicity than those with an AUC $1350 \mathrm{mg} \mathrm{h} / \mathrm{L}$ (odds ratio 4.4 and 4.5, respectively). The odds of developing hepato- and neurotoxicity were also higher in the former group, but the difference did not reach statistical significance. No association was found between treosulfan exposure and early clinical outcomes, i.e., engraftment, donor chimerism, acute graft-versushost disease, treatment-related mortality, and overall survival. PK parameters were shown to be age-dependent, with higher AUC values in younger children $(<1$ year old) and corresponding lower treosulfan clearance. A challenge in therapeutic monitoring of treosulfan within conditioning prior to HCT is a very brief course of treatment, consisting of three doses administered on 3 consecutive days. This allows personalization of only the second and third dose of the prodrug unless a test dose is applied prior to starting the actual regimen.

Since pharmacokinetic studies of treosulfan began, it has been assumed that plasma (serum) concentrations of the prodrug are a good representation of the alkylating activity of its epoxy transformers. However, for years, a correlation between treosulfan concentrations in plasma and levels of specific DNA adducts in tissues, for example the bone marrow, or clinical effects, have not been investigated. Therapeutic drug monitoring of not only prodrug but also its active epoxide might be needed. In addition blood $\mathrm{pH}$, body temperature, and intravenous fluid delivery may influence glomerular filtration, tubular reabsorption, and nonenzymatic epoxy transformation of the prodrug [53].

\section{Serotherapy Levels}

It is now well recognized that type of serotherapy, dose and timing in relation to the transplant all have an impact on outcome of transplant in terms of occurrence of GVHD, immune reconstitution importantly in terms of viral reactivation, clearance of infection, and chimerism. Marsh RA et al. collected data from 105 patients to examine the influence of peritransplant alemtuzumab levels on acute GVHD, mixed chimerism, and lymphocyte recovery. Significantly higher levels of aGVHD but higher levels of donor chimerism, lymphocyte counts at D+30 and $\mathrm{T}$ cell counts at D+100 were associated with lower alemtuzumab levels at day 0 [54].

In a recent report, the clearance of the active components of the 2 widely used types of ATG (Fresenius/ Grafalon and Genzyme) was studied in 38 children with malignant hematological disorders. They found that ATG Fresenius was cleared rapidly and uniformly from the circulation whether they received $60 \mathrm{mg} / \mathrm{kg}$ or $45 \mathrm{mg} / \mathrm{kg}$, but there were significant differences in patients who received a high dose of ATG Genzyme (10 mg/kg) who had significantly slower reconstitution for CD3, CD4, and CD8 T cells compared to patients who received a low dose of ATG Genzyme (6-8 mg/kg) or ATG Fresenius [55]. 


\section{Stem Cell Source in Non-MAC Conditioning}

Historically bone marrow has been the preferred stem cell source for HCT in children due to concerns that peripheral blood stem cell products led to an increased risk of GVHD. In Slatter et al.'s report of 160 PID patients who received uniform conditioning with treosulfan and fludarabine, a higher level of myeloid chimerism was found in recipients of PBSC compared to $\mathrm{CB}$ and $\mathrm{BM}$, without an increased risk of grade III/IV acute or chronic GvHD [26]. This is an important finding particularly for patients with diseases where a high level of chimerism is required to achieve complete cure.

\section{Conclusions}

The use of RTC and RIC has been a major paradigm shift in HCT for PID and may have contributed to improved survival through a reduction in early post-HSCT toxicities. Almost certainly, long-term toxicities will be reduced, although further data are required to confirm this. However, the use of antibody-based conditioning regimens is likely to transform the field in the future. The drive for this has been that PID can be completely cured by HCT, and as malignancy is rarely a feature of the disease, toxicity from the curative procedure should be minimized. More recently, newborn screening for severe combined immunodeficiencies has meant that these patients are now being identified by 2-3 weeks of age [56]. Rapid transplantation is preferred, as survival and neurological outcome results are best in patients with no preexisting infection $[57,58]$. As gene therapy approaches become mainstream treatment, then a non-toxic conditioning approach followed by an autologous gene-corrected stem cell procedure should almost eliminate short- and long-term treatment-related morbidities for patients with SCID $[59,60]$. These conditioning approaches will have to be modified for combined immunodeficiencies and gain-of-function diseases where high-level or complete donor chimerism is required to abolish disease manifestations [61-64]. However, combinations of antibody-based regimens and pharmacokinetically targeted reduced lowtoxicity agents may help resolve these issues. The future for patients with PID looks extremely encouraging.

\section{Compliance with Ethical Standards}

Conflict of Interest The authors declare no conflicts of interest relevant to this manuscript.

Human and Animal Rights and Informed Consent This article does not contain any studies with human or animal subjects performed by any of the authors.
Open Access This article is distributed under the terms of the Creative Commons Attribution 4.0 International License (http:// creativecommons.org/licenses/by/4.0/), which permits unrestricted use, distribution, and reproduction in any medium, provided you give appropriate credit to the original author(s) and the source, provide a link to the Creative Commons license, and indicate if changes were made.

\section{References}

Papers of particular interest, published recently, have been highlighted as:

- Of importance

•. Of major importance

1. Gatti RA, Meuwissen HJ, Allen HD, Hong R, Good RA. Immunological reconstitution of sex-linked lymphopenic immunological deficiency. Lancet. 1968;2(7583):1366-9.

2. Bach FH, Albertini RJ, Joo P, Anderson JL, Bortin MM. Bonemarrow transplantation in a patient with the Wiskott-Aldrich syndrome. Lancet. 1968;2(7583):1364-6.

3. Slatter MA, Gennery AR. Hematopoietic cell transplantation in primary immunodeficiency - conventional and emerging indications. Expert Rev Clin Immunol. 2018;14(2):103-14.

4. Slatter MA, Gennery AR. Advances in hematopoietic stem cell transplantation for primary immunodeficiency. Expert Rev Clin Immunol. 2013;9(10):991-9 An expert review on new indications of HCT in children with PID.

5.• Shah RM, Elfeky R, Nademi Z, Qasim W, Amrolia P, Chiesa R, et al. T-cell receptor alphabeta(+) and CD19(+) cell-depleted haploidentical and mismatched hematopoietic stem cell transplantation in primary immune deficiency. J Allergy Clin Immunol. 2018;141(4):1417-26 e1. An important paper demonstrating excellent transplant outcome after haploidentical donor transplant using graft engineering for children with PID.

6. Fischer A, Landais P, Friedrich W, Gerritsen B, Fasth A, Porta F, et al. Bone marrow transplantation (BMT) in Europe for primary immunodeficiencies other than severe combined immunodeficiency: a report from the European Group for BMT and the European Group for Immunodeficiency. Blood. 1994;83(4):1149-54.

7. Klein C, Cavazzana-Calvo M, Le Deist F, Jabado N, Benkerrou M, Blanche S, et al. Bone marrow transplantation in major histocompatibility complex class II deficiency: a single-center study of 19 patients. Blood. 1995;85(2):580-7.

8. Antoine C, Muller S, Cant A, Cavazzana-Calvo M, Veys P, Vossen $\mathrm{J}$, et al. Long-term survival and transplantation of haemopoietic stem cells for immunodeficiencies: report of the European experience 1968-99. Lancet. 2003;361(9357):553-60.

9. Renella R, Picard C, Neven B, Ouachee-Chardin M, Casanova JL, Le Deist F, et al. Human leucocyte antigen-identical haematopoietic stem cell transplantation in major histocompatiblity complex class II immunodeficiency: reduced survival correlates with an increased incidence of acute graft-versus-host disease and pre-existing viral infections. Br J Haematol. 2006;134(5):510-6.

10. Malar R, Sjoo F, Rentsch K, Hassan M, Gungor T. Therapeutic drug monitoring is essential for intravenous busulfan therapy in pediatric hematopoietic stem cell recipients. Pediatr Transplant. 2011;15(6): $580-8$.

11.• Slatter MA, Rao K, Abd Hamid IJ, Nademi Z, Chiesa R, Elfeky R, et al. Treosulfan and fludarabine conditioning for hematopoietic stem cell transplantation in children with primary immunodeficiency: UK experience. Biol Blood Marrow Transplant. 2018;24(3): 
529-36 An important study in a large cohort of PID patient received treosulfan demonstrating excellent survival, chimerism and low toxicity.

12. Morillo-Gutierrez B, Beier R, Rao K, Burroughs L, Schulz A, Ewins AM, et al. Treosulfan-based conditioning for allogeneic HSCT in children with chronic granulomatous disease: a multicenter experience. Blood. 2016;128(3):440-8.

13. Slatter MA, Boztug H, Potschger U, Sykora KW, Lankester A, Yaniv I, et al. Treosulfan-based conditioning regimens for allogeneic haematopoietic stem cell transplantation in children with nonmalignant diseases. Bone Marrow Transplant. 2015;50(12):153641.

14. Burroughs LM, Nemecek ER, Torgerson TR, Storer BE, Talano JA, Domm J, et al. Treosulfan-based conditioning and hematopoietic cell transplantation for nonmalignant diseases: a prospective multicenter trial. Biol Blood Marrow Transplant. 2014;20(12):19962003 A large multicentre study demonstrating the safety and excellent transplant survival using Treosulfan-based conditiniong for nonmaligant diseases.

15. Dinur-Schejter Y, Krauss AC, Erlich O, Gorelik N, Yahel A, Porat I, et al. Bone marrow transplantation for non-malignant diseases using treosulfan-based conditioning. Pediatr Blood Cancer. 2015;62(2):299-304.

16. Lehmberg K, Albert MH, Beier R, Beutel K, Gruhn B, Kroger N, et al. Treosulfan-based conditioning regimen for children and adolescents with hemophagocytic lymphohistiocytosis. Haematologica. 2014;99(1):180-4.

17. Beier R, Schulz A, Honig M, Eyrich M, Schlegel PG, Holter W, et al. Long-term follow-up of children conditioned with Treosulfan: German and Austrian experience. Bone Marrow Transplant. 2013;48(4):491-501.

18. Slatter MA, Rao K, Amrolia P, Flood T, Abinun M, Hambleton S, et al. Treosulfan-based conditioning regimens for hematopoietic stem cell transplantation in children with primary immunodeficiency: United Kingdom experience. Blood. 2011;117(16):4367-75.

19. Dvorak CC, Long-Boyle J, Dara J, Melton A, Shimano KA, Huang $\mathrm{JN}$, et al. Low exposure busulfan conditioning to achieve sufficient multilineage chimerism in patients with severe combined immunodeficiency. Biol Blood Marrow Transplant. 2019;25(7):1355-62.

20.• Gungor T, Teira P, Slatter M, Stussi G, Stepensky P, Moshous D, et al. Reduced-intensity conditioning and HLA-matched haemopoietic stem-cell transplantation in patients with chronic granulomatous disease: a prospective multicentre study. Lancet. 2014;383(9915):436-48 A landmark study which demonstrates excellent transplant outcome using Bu-Flu in children with chronic granulomatous disease.

21. Jacobsohn DA, Duerst R, Tse W, Kletzel M. Reduced intensity haemopoietic stem-cell transplantation for treatment of nonmalignant diseases in children. Lancet. 2004;364(9429):156-62.

22. Allen CE, Marsh R, Dawson P, Bollard CM, Shenoy S, Roehrs P, et al. Reduced-intensity conditioning for hematopoietic cell transplant for HLH and primary immune deficiencies. Blood. 2018;132(13):1438-51.

23. Fox TA, Chakraverty R, Burns S, Carpenter B, Thomson K, Lowe $\mathrm{D}$, et al. Successful outcome following allogeneic hematopoietic stem cell transplantation in adults with primary immunodeficiency. Blood. 2018;131(8):917-31.

24. Straathof KC, Rao K, Eyrich M, Hale G, Bird P, Berrie E, et al. Haemopoietic stem-cell transplantation with antibody-based minimal-intensity conditioning: a phase $1 / 2$ study. Lancet. 2009;374(9693):912-20.

25. Ritchie DS, Morton J, Szer J, Roberts AW, Durrant S, Shuttleworth $\mathrm{P}$, et al. Graft-versus-host disease, donor chimerism, and organ toxicity in stem cell transplantation after conditioning with fludarabine and melphalan. Biol Blood Marrow Transplant. 2003;9(7):435-42.
26. Unni MNM, Elfeky R, Rao K, Nademi Z, Chiesa R, Amrolia P, et al. Non-posttransplant lymphoproliferative disorder malignancy after hematopoietic stem cell transplantation in patients with primary immunodeficiency: UK experience. J Allergy Clin Immunol. 2018;141(6):2319-21 e1.

27. Haskologlu S, Kostel Bal S, Islamoglu C, Altun D, Kendirli T, Dogu EF, et al. Outcome of treosulfan-based reduced-toxicity conditioning regimens for HSCT in high-risk patients with primary immune deficiencies. Pediatr Transplant. 2018;22(7):e13266.

28. Ben-Barouch S, Cohen O, Vidal L, Avivi I, Ram R. Busulfan fludarabine vs busulfan cyclophosphamide as a preparative regimen before allogeneic hematopoietic cell transplantation: systematic review and meta-analysis. Bone Marrow Transplant. 2016;51(2):232-40.

29. Harris AC, Boelens JJ, Ahn KW, Fei M, Abraham A, Artz A, et al. Comparison of pediatric allogeneic transplant outcomes using myeloablative busulfan with cyclophosphamide or fludarabine. Blood Adv. 2018;2(11):1198-206.

30. Marsh RA, Vaughn G, Kim MO, Li D, Jodele S, Joshi S, et al. Reduced-intensity conditioning significantly improves survival of patients with hemophagocytic lymphohistiocytosis undergoing allogeneic hematopoietic cell transplantation. Blood. 2010;116(26): 5824-31.

31. Amrolia P, Gaspar HB, Hassan A, Webb D, Jones A, Sturt N, et al. Nonmyeloablative stem cell transplantation for congenital immunodeficiencies. Blood. 2000;96(4):1239-46.

32. Ritchie DS, Seymour JF, Roberts AW, Szer J, Grigg AP. Acute left ventricular failure following melphalan and fludarabine conditioning. Bone Marrow Transplant. 2001;28(1):101-3.

33. Marsh RA, Bleesing JJ, Chandrakasan S, Jordan MB, Davies SM, Filipovich AH. Reduced-intensity conditioning hematopoietic cell transplantation is an effective treatment for patients with SLAMassociated protein deficiency/X-linked lymphoproliferative disease type 1. Biol Blood Marrow Transplant. 2014;20(10):1641-5.

34. Ono S, Okano T, Hoshino A, Yanagimachi M, Hamamoto K, Nakazawa Y, et al. Hematopoietic stem cell transplantation for XIAP deficiency in Japan. J Clin Immunol. 2017;37(1):85-91.

35. Burroughs LM, Storb R, Leisenring WM, Pulsipher MA, Loken MR, Torgerson TR, et al. Intensive postgrafting immune suppression combined with nonmyeloablative conditioning for transplantation of HLA-identical hematopoietic cell grafts: results of a pilot study for treatment of primary immunodeficiency disorders. Bone Marrow Transplant. 2007;40(7):633-42.

36. Burroughs LM, Torgerson TR, Storb R, Carpenter PA, Rawlings DJ, Sanders J, et al. Stable hematopoietic cell engraftment after lowintensity nonmyeloablative conditioning in patients with immune dysregulation, polyendocrinopathy, enteropathy, X-linked syndrome. J Allergy Clin Immunol. 2010;126(5):1000-5.

37. Schuetz C, Neven B, Dvorak CC, Leroy S, Ege MJ, Pannicke U, et al. SCID patients with ARTEMIS vs RAG deficiencies following HCT: increased risk of late toxicity in ARTEMIS-deficient SCID. Blood. 2014;123(2):281-9.

38. Slack J, Albert MH, Balashov D, Belohradsky BH, Bertaina A, Bleesing $\mathrm{J}$, et al. Outcome of hematopoietic cell transplantation for DNA double-strand break repair disorders. J Allergy Clin Immunol. 2018;141(1):322-8 e10.

39. Haddad E, Logan BR, Griffith LM, Buckley RH, Parrott RE, Prockop SE, et al. SCID genotype and 6-month posttransplant CD4 count predict survival and immune recovery. Blood. 2018;132(17):1737-49.

40. Ali AM, Dehdashti F, DiPersio JF, Cashen AF. Radioimmunotherapy-based conditioning for hematopoietic stem cell transplantation: another step forward. Blood Rev. 2016;30(5): 389-99.

41. Pagel JM, Appelbaum FR, Eary JF, Rajendran J, Fisher DR, Gooley $\mathrm{T}$, et al. 131I-anti-CD45 antibody plus busulfan and 
cyclophosphamide before allogeneic hematopoietic cell transplantation for treatment of acute myeloid leukemia in first remission. Blood. 2006;107(5):2184-91.

42. Pagel JM, Gooley TA, Rajendran J, Fisher DR, Wilson WA, Sandmaier BM, et al. Allogeneic hematopoietic cell transplantation after conditioning with $131 \mathrm{I}$-anti-CD45 antibody plus fludarabine and low-dose total body irradiation for elderly patients with advanced acute myeloid leukemia or high-risk myelodysplastic syndrome. Blood. 2009;114(27):5444-53.

43. Mawad R, Gooley TA, Rajendran JG, Fisher DR, Gopal AK, Shields AT, et al. Radiolabeled anti-CD45 antibody with reducedintensity conditioning and allogeneic transplantation for younger patients with advanced acute myeloid leukemia or myelodysplastic syndrome. Biol Blood Marrow Transplant. 2014;20(9):1363-8.

44. Schulz AS, Glatting G, Hoenig M, Schuetz C, Gatz SA, Grewendorf S, et al. Radioimmunotherapy-based conditioning for hematopoietic cell transplantation in children with malignant and nonmalignant diseases. Blood. 2011;117(17):4642-50.

45. Derderian SC, Jeanty C, Walters MC, Vichinsky E, MacKenzie TC. In utero hematopoietic cell transplantation for hemoglobinopathies. Front Pharmacol. 2014;5:278.

46. Agarwal R, Dvora CC, Proshaska S, et al. Toxicity-free hematopoietic stem cell engraftment achieved with anti-CD117 monoclonal antibody conditioning. Biol Blood Marrow Transplant. 2019;25: S92.

47. Rastogi N, Katewa S, Thakkar D, Kohli S, Nivargi S, Yadav SP. Reduced-toxicity alternate-donor stem cell transplantation with posttransplant cyclophosphamide for primary immunodeficiency disorders. Pediatric Blood Cancer. 2018;65(1).

48. Neven B, Diana JS, Castelle M, Magnani A, Rosain J, Touzot F, et al. Haploidentical hematopoietic stem cell transplantation with post-transplant cyclophosphamide for primary immunodeficiencies and inherited disorders in children. Biol Blood Marrow Transplant. 2019;25(7):1363-73.

49. Rao K, Amrolia PJ, Jones A, Cale CM, Naik P, King D, et al. Improved survival after unrelated donor bone marrow transplantation in children with primary immunodeficiency using a reducedintensity conditioning regimen. Blood. 2005;105(2):879-85.

50. Chiesa R, Veys P. Reduced-intensity conditioning for allogeneic stem cell transplant in primary immune deficiencies. Expert Rev Clin Immunol. 2012;8(3):255-66 quiz 67.

51. Balashov D, Shcherbina A, Maschan M, Trakhtman P, Skvortsova Y, Shelikhova L, et al. Single-center experience of unrelated and haploidentical stem cell transplantation with TCRalphabeta and CD19 depletion in children with primary immunodeficiency syndromes. Biol Blood Marrow Transplant. 2015;21(11):1955-62.

52. Ivaturi V, Dvorak CC, Chan D, Liu T, Cowan MJ, Wahlstrom J, et al. Pharmacokinetics and model-based dosing to optimize fludarabine therapy in pediatric hematopoietic cell transplant recipients. Biol Blood Marrow Transplant. 2017;23(10):1701-13.

53. Romanski M, Wachowiak J, Glowka FK. Treosulfan pharmacokinetics and its variability in pediatric and adult patients undergoing conditioning prior to hematopoietic stem cell transplantation: current state of the art, in-depth analysis, and perspectives. Clin Pharmacokinet. 2018;57(10):1255-65.

54. Marsh RA, Lane A, Mehta PA, Neumeier L, Jodele S, Davies SM, et al. Alemtuzumab levels impact acute GVHD, mixed chimerism, and lymphocyte recovery following alemtuzumab, fludarabine, and melphalan RIC HCT. Blood. 2016;127(4):503-12.

55. Oostenbrink LVE, Jol-van der Zijde CM, Kielsen K, JansenHoogendijk AM, Ifversen M, Muller KG, et al. Differential elimination of anti-thymocyte globulin of Fresenius and Genzyme impacts T-cell reconstitution after hematopoietic stem cell transplantation. Front Immunol. 2019;10:315.

56. Kwan A, Abraham RS, Currier R, Brower A, Andruszewski K, Abbott JK, et al. Newborn screening for severe combined immunodeficiency in 11 screening programs in the United States. JAMA. 2014;312(7):729-38.

57. Pai SY, Logan BR, Griffith LM, Buckley RH, Parrott RE, Dvorak $\mathrm{CC}$, et al. Transplantation outcomes for severe combined immunodeficiency, 2000-2009. N Engl J Med. 2014;371(5):434-46.

58. Dvorak CC, Puck JM, Wahlstrom JT, Dorsey M, Melton A, Cowan MJ. Neurologic event-free survival demonstrates a benefit for SCID patients diagnosed by newborn screening. Blood Adv. 2017;1(20): $1694-8$.

59. Cicalese MP, Ferrua F, Castagnaro L, Pajno R, Barzaghi F, Giannelli S, et al. Update on the safety and efficacy of retroviral gene therapy for immunodeficiency due to adenosine deaminase deficiency. Blood. 2016;128(1):45-54.

60. Mamcarz E, Zhou S, Lockey T, Abdelsamed H, Cross SJ, Kang G, et al. Lentiviral gene therapy combined with low-dose busulfan in infants with SCID-X1. N Engl J Med. 2019;380(16):1525-34.

61. Moratto D, Giliani S, Bonfim C, Mazzolari E, Fischer A, Ochs HD, et al. Long-term outcome and lineage-specific chimerism in 194 patients with Wiskott-Aldrich syndrome treated by hematopoietic cell transplantation in the period 1980-2009: an international collaborative study. Blood. 2011;118(6):1675-84.

62. Battersby AC, Braggins H, Pearce MS, Cale CM, Burns SO, Hackett $\mathrm{S}$, et al. Inflammatory and autoimmune manifestations in $\mathrm{X}$-linked carriers of chronic granulomatous disease in the United Kingdom. J Allergy Clin Immunol. 2017;140(2):628-30 e6.

63. Seidel MG, Bohm K, Dogu F, Worth A, Thrasher A, Florkin B, et al. Treatment of severe forms of LPS-responsive beige-like anchor protein deficiency with allogeneic hematopoietic stem cell transplantation. J Allergy Clin Immunol. 2018;141(2):770-5 e1.

64. Leiding JW, Okada S, Hagin D, Abinun M, Shcherbina A, Balashov DN, et al. Hematopoietic stem cell transplantation in patients with gain-of-function signal transducer and activator of transcription 1 mutations. J Allergy Clin Immunol. 2018;141(2): 704-17 e5.

Publisher's Note Springer Nature remains neutral with regard to jurisdictional claims in published maps and institutional affiliations. 